\title{
Influence of Weed Competition on Potato Growth, Production and Radiation Use Efficiency
}

\author{
Farzad MONDANI ${ }^{1}$, Farid GOLZARDI², Godarz AHMADVAND, \\ Reza GHORBANI', Rooholla MORADI ${ }^{1 *}$ \\ ${ }^{1}$ Ferdowsi University of Mashhad, Faculty of Agriculture, Department of Agronomy, Iran; Roholla18@gmail.com (*corresponding author) \\ ${ }^{2}$ Young Researchers Club, Karaj Branch, Islamic Azad University, Karaj, Iran \\ ${ }^{3}$ Bu-Ali Sina University of Hamedan, Faculty of Agriculture, Iran
}

\begin{abstract}
Weed management in potato production is one of the main cost and time consuming practices. Understanding the most effective time of weed control could reduce the costs and increase potato yield. Field study was conducted in the west region of Iran during 2006 to evaluate the effect of weeds damage in potato fields. Twelve treatments used consisted of six initial weed-free periods in which plots were kept free of weeds for $0,10,20,30,40$ and 50 days after crop emergence (DAE), and then weeds were allowed to grow until harvest, and six initial weed-infested periods in which, weeds were allowed to grow for 0, 10, 20, 30, 40 and $50 \mathrm{DAE}$, then the plots were kept free of weeds until harvest. Experiment was arranged as a randomized complete block design with three replications. The results showed effect of weed competition on crop dry matter started about $40 \mathrm{DAE}$ and about $90 \mathrm{DAE}$ reached its maximum. The weeds competition decreased dry matter accumulation, leaf area index, crop growth rate, leaf area index duration, light absorption, light extinction coefficient and radiation use efficiency (RUE) of potato. Weeds reduced the potato yield 54.8 percent. The beginning and the end of the critical period of weed control in potato (CPWC) was based on 5\% and 10\% tuber yield loss. The onset of the CPWC ranged from 486 to 572 GDD, at $5 \%$ and $10 \%$ yield loss level corresponding to 11 and 19 days after crop emergence, respectively. The end of the CPWC varied from 1372 to $1164 \mathrm{GDD}$, at $5 \%$ and $10 \%$ yield loss level corresponding to 65 and 51 days after crop emergence, respectively. RUE in the weed infestation treatment in comparison to the weed free treatment, reduced 11.8 percent.
\end{abstract}

Keywords: critical period, light extinction coefficient, light absorption, potato tuber yield

\section{Introduction}

Potato is an annual crop which plays an important role in human's source of food. Potato tubers have various nutrients such as carbohydrates, proteins and various amino acids. Weed infestation decrease the quality and quantity of potato tubers via decreasing size, weight and number of tubers (Arnold et al., 1998). Competition affects considerably the shape, size and function of competing species. Growth analysis of competing species is the realization of the source of limitation and its effect on plant populations (Shurong et al., 1993). So, Spitters and Kramer (1986) stated that information on the crops growth characteristics help the better understanding of their pattern of competition. Roush and Radosevich (1985) noticed that crop biomass is the most simple and rapid measure of species competition. Spitters and Kramer (1986) also stated that since biomass has direct relationships with absorption of limiting resources, it can be used as a suitable index for evaluation competition effects on the crop growth.

John and Frank (1983) believed that the factors affecting competition are somehow reflected in canopy development. Therefore measuring canopy characteristics integrates the entire crop or weed competition parameters for example species growth characteristics, density and relative emergence time. Hargood et al. (1981) stated that crop growth rate, leaf area index and dry mater accumulation are suitable scales of crop function which can affect competitiveness. Light is one of the important factors affecting crop respondent weed competition which is related to leaf area index, light extinction coefficient and intensity of weed shading on crop (Cooper, 1977). Growth rate and production is highly dependent on leaf area and absorption of incoming radiation by closed canopy (Muurinen and Peltonen-Sainio, 2006). Variability in RUE values can be explained in terms of physical and biological factors (Rouphael and Colla, 2005). Weed competition is one of the biological factors can be affect on RUE via changing crop growth characteristics. Board et al. (1990) reported that dry matter production and light absorption period increased by increasing leaf area index which can be associated with more yield.

Crops yield will decrease significantly by weed interference. Therefore, effective weed management dependents on knowledge about the effect of competition on yield and yield components (Elkoca et al., 2005). Response of the yield and yield component to weeds competition is different in crop species during the growth period. Yield component in growth duration shows the maximum sen- 
sitivity to weed competition (Stephen et al., 2003). Due to a long time from sowing to emergence of potato fields, and the long distance among the rows, weeds have enough area to growth using abundant water and nutrients which directly leads to rapid growth of weeds and decreasing the crop yield (Arnold et al., 1998). Therefore, weeds must be removed in an appropriate time for achieving to optimum yield in potato fields. Weed control allocated a notable part of production costs and increases herbicide use and pollution (Hall et al., 1992; Morin et al., 2009).

Determination of the critical period of weed control (CPWC) can be useful for increasing the herbicides consumption efficiency and decreasing the environmental hazards consequently (Knezevic et al., 2002). In this period weed management prevents the weed interference and crops yield reduction. In various studies, the critical period has commonly been defined as days after emergence (DAE) or weeks after emergence (WAE). However, critical period have been reported as growing degree days (GDD) or crop growth stage in recently studies, which would be applicable for comparing critical period across different locations and environmental conditions (Stagnari and Pisante, 2011). Baziramkenga and Leroux (1994) suggested that for obtaining the optimum tuber yield, the maximum time that allowed to weeds to grow after potato emergence was 15 days, and the value of tuber yield could be achieved if the crop was kept free of weeds from its emergence until 23 to 68 days. Amador-Ramirez (2002) also stated that the onset of CPWC in chili pepper at 5\% acceptable yield loss level (AYL) was 0.7-3.2 weeks after emergence (WAE) and the end of CPWC was 7.4-14.7 WAE. The onset of CPWC was 1.3-4.5 WAE and the end of CPWC was 6.3-12.4 WAE at 10\% AYL.

The objective of the present study was to evaluate the effect of weed interference periods on growth characteristics, tuber yield and radiation use efficiency of potato

\section{Materials and methods}

\section{Site description}

A field experiment was conducted during 2006 at the Agricultural Research Station of Hamedan (34 $52^{\prime}$ ' N latitude, $48^{\circ} 32^{\prime}$ W longitude and $1741.5 \mathrm{~m}$ a.s.l.), in the west region of Iran. The soil type was a sandy loam with a $\mathrm{pH}$ of 8.2 and $0.9 \%$ organic matter. The land was ploughed and cultivated before planting. No pre-emergence or presowing herbicide was used. According to the local soil test recommendations, basal doses of $400 \mathrm{~kg} \mathrm{ha}^{-1}$ Urea, $100 \mathrm{~kg}$ $\mathrm{ha}^{-1}$ Triple Super Phosphate and $200 \mathrm{~kg} \mathrm{ha}^{-1}$ Potassium Sulfate were incorporated into the soil. All phosphate and potassium and $1 / 3$ of urea fertilizers were used in the planting stage, and the remainder urea was applied at two stages (one week before and in the middle of tuber formation). In order to protect potato tubers against soil-borne diseases, they were treated with Ditan 45T1 [Mankozeb in $0.8 \%(\mathrm{w} / \mathrm{w})]$ before sowing. The crop was planted on $\mathrm{min}$
April, 2006. Crop emergence began about 20 days after planting. Each plot consisted of four rows ( $8 \mathrm{~m}$ per row) with a row spacing of $75 \mathrm{~cm}$. Final potato plant density was 5.3 plant $\mathrm{m}^{-2}$ (optimum plant density of commercial potato production). In this experiment potato tubers $\mathrm{cv}$. Agria (Elite seed class) were used in a field infested with natural weed population.

\section{Experimental design}

The experiment was carried out as a randomized complete block design with three replications and twelve treatments. The experimental treatments consisted of a quantitative series of both increasing duration of weed interference and length of weed-free periods, Twelve treatments including six initial weed-free periods in which plots were kept free of weeds for 0 (seasonal-long weed infested), $10\left(\mathrm{WF}_{10}\right), 20\left(\mathrm{WF}_{20}\right), 30\left(\mathrm{WF}_{30}\right), 40\left(\mathrm{WF}_{40}\right)$ and 50 $\left(\mathrm{WF}_{50}\right.$ ) days after crop emergence (DAE), and then weeds were allowed to grow until harvest, and six initial weedinfested periods in which, weeds were allowed to grow for 0 (seasonal-long weed free), $10\left(\mathrm{WI}_{10}\right), 20\left(\mathrm{WI}_{20}\right), 30$ $\left(\mathrm{WI}_{30}\right), 40\left(\mathrm{WI}_{40}\right)$ and $50\left(\mathrm{WI}_{50}\right) \mathrm{DAE}$, after that the plots were kept free of weeds until harvest were used.

\section{Weed and crop measurement}

Weeds began to emerge on the 5 days after crop planting, and species were the common representation potato fields in west regions of Iran. At mean sampling events, Chenopodium album L., Amaranthus blitoides L., Amaranthus retroflexus $\mathrm{L}$. and Convolvulus arvensis $\mathrm{L}$. were the most abundant weed species. One day before each weedremoval event, weeds were sampled at the end of weed infestation period in weed infestation treatments with a 1.0 $\times 1.0$ meter quadrate per plot (before each weed removal event) and at harvest for weed-free treatments. Weeds dry matter was determined after drying at $80^{\circ} \mathrm{C}$ for 48 hours maintaining constant moisture content. Potato sampling was started 10 days after tubers emergence and then repeated for 10 times in all treatments. Three potato plants were harvested from each plot in each sampling.

\section{Data analysis}

After determining the potato leaf area, samples were dried at $70^{\circ} \mathrm{C}$ for 48 hours and then weighted. The best equations that described the total dry matter accumulation and leaf area index from regression method were chosen using Slide write software. Crop growth rate (CGR), was calculated by following equation (1) (Gardner et al., 1985):

$$
\mathbf{C G R}=\left(\mathbf{W}_{2}-\mathbf{W}_{1}\right) /\left[\left(\mathbf{t}_{2}-\mathbf{t}_{1}\right) \times \mathbf{G}_{\mathrm{A}}\right]
$$

Where CGR is the crop growth rate $\left(\mathrm{g} \mathrm{m}^{-2}\right.$ day $\left.^{-1}\right) \mathrm{W}_{1}$ and $\mathrm{W}_{2}$ are total dry weight at two successive sampling dates $\left(\mathrm{g} \mathrm{m}^{-2}\right)$, respectively, $t_{1}$ and $t_{2}$ are time of first and second of sampling, respectively and $G_{A}$ is sampling area $\left(\mathrm{m}^{2}\right)$. Leaf area index duration (LAID) was calculated by using the following equation (2) (Gardner et al., 1985): 
44

$$
\mathrm{LAID}=\Sigma\left[\left(\mathrm{LAI}_{2}+\mathrm{LAI}_{1}\right) / 2\left(\mathrm{t}_{2}-\mathrm{t}_{1}\right)\right]
$$

Where LAID is the leaf area index duration, on the basis of LAI in day, $\mathrm{LAI}_{1}$ and $\mathrm{LAI}_{2}$ are leaf area indices at two sampling dates, respectively

\section{Light measurement}

In order to determine light absorption by potato canopy in each treatment, the amount of light in the top and under the canopy was measured from $10 \mathrm{DAE}$ at 10 -day intervals for 8 times by tube spectrometer (LICOR-LI250-A model). Weeds were removed before light measurement in the infested treatments. Potato light absorption was calculated with the following equation (3) (Gardner et al., 1985) and Light Extinction Coefficient (K), as the slope of linear regressing between $-\ln \left(\mathrm{I} / \mathrm{I}_{0}\right)$ and LAI, (equation 4) (Gardner et al., 1985):

$$
\begin{aligned}
& \% \mathrm{I}_{\text {abs }}=\left(\mathrm{I}_{0}-\mathrm{I}\right) / \mathrm{I}_{0} \times 100 \\
& \mathrm{Ln}\left(\mathrm{I} / \mathrm{I}_{0}\right)=-\mathrm{K} \times \mathrm{LAI}
\end{aligned}
$$

$\operatorname{Ln}\left(\mathbf{I} / \mathrm{I}_{0}\right)=-\mathrm{K} \times \mathbf{L A I}$

Where $\% \mathrm{I}_{\text {abs }}$ is the light absorbed by the potato canopy, $\mathrm{I}_{0}$ is over canopy light, $\mathrm{I}$ is under canopy light and $\mathrm{K}$ is Light Extension Coefficient. To calculate the amount of daily radiation latitude, sunny hours and angstrom coefficient were used (Bange et al., 1997; Nassiri Mahallati, 1998). In this study absorbed photosynthetically active radiation (PAR) was $50 \%$ of the total radiation. Total absorbed light in each treatment was determined from the percentage of light absorbed multiplied by the total radiation incoming in to the canopy. Radiation use efficiency (RUE) on the basis of g.MJ ${ }^{-1}$ was calculated through the slope of linear regressing between dry matter accumulation $\left(\mathrm{g} \mathrm{m}^{-2}\right)$ and total absorbed photosynthetically active radiation (PAR) (Bange et al., 1997; Nassiri Mahallati, 1998). In order to determine the trend of light absorption, the best equations which describe the changes of light absorption over the time were selected from regressing method using Slide write software.

\section{Yield and critical period of weed control (CPWC)}

Crop yield at full maturity was measured from two square meters in two central rows. To determine the critical period of weed control in potato equations for showing relationship between relative yield of potato and weedinterference were fitted by using of nonlinear regression. The Gompertz equation (5) (Ratkowsky, 1990) was used to describe the effect of increasing duration of weed-free period on potato tuber yield:

$$
\mathrm{Y}=\mathrm{A} \times \exp [-\mathrm{B} \times \exp (-\mathrm{K} \times \mathrm{GDD})]
$$

Where $\mathrm{Y}$ is the yield as a percentage of the weedfree control, $\mathrm{A}$ is the upper asymptote, $\mathrm{B}$ and $\mathrm{K}$ are parameters that determine the shape of the curve, and GDD is the length of the weed-free period after crop planting on basis of growing degree days.

A logistic equation (6) (Ratkowsky, 1990) was used to describe the effect of increasing lengths of weed-infested period on the tuber yield of potato:

$$
\mathrm{Y}=\mathrm{C}+(\mathrm{D} /[1+\exp (-\mathrm{A}+\mathrm{B} \times \mathrm{GDD})])
$$

Where $\mathrm{Y}$ is the yield as a percentage of the weed-free control, $\mathrm{A}$ and $\mathrm{B}$ are parameters that determine the shape of the curve, $\mathrm{C}$ is the lower asymptote, $\mathrm{D}$ is the difference between the upper and lower asymptotes and GDD is the duration of weed interference measured from the time of planting in growing degree days $\left({ }^{\circ} \mathrm{C}\right)$. Growing degree days (GDD) from the crop emergence were determined using minimum and maximum air temperature from a nearby weather station. A base temperature $\left(\mathrm{T}_{\mathrm{b}}\right)$ of $4^{\circ} \mathrm{C}$ a maximum temperature of $30^{\circ} \mathrm{C}$ was used as the minimum and maximum temperatures for potato growth, respectively. Determination of the CPWC in this study was on the basis of arbitrarily chosen yield loss levels of 5\% and $10 \%$. This yield loss level was judged to be acceptable, taking into account the present economics of weed control, e.g. the cost of weed control, potato prices and tuber yield. The relationships between treatments and weed biomass were described using PROC REG in SAS (SAS Institute, 1999). The relationship between weed dry weight and the treatments was described using an exponential equation (7) to the series of weed-free treatments (Sit and Costello, 1994):

$$
\mathrm{Y}=\mathrm{a}^{\mathrm{bx}}
$$

Where, $\mathrm{Y}$ is the weed dry weight $\left(\mathrm{g} \mathrm{m}^{-2}\right), a$ and $b$ are constants of curve and $\mathrm{X}$ is the length of weed-free period (in GDD). Schumacher's (1939) model was fitted to the weed-infested treatments and weed biomass accumulation.

$$
\mathrm{Y}=\mathrm{e}^{\mathrm{a}+\mathrm{b} / \mathrm{x}}
$$

Where, $\mathrm{Y}$ is the weed dry weight $\left(\mathrm{g} \mathrm{m}^{-2}\right), a$ and $b$ are constants of curve and $\mathrm{X}$ is the duration of weed infested period (in GDD).

\section{Results and discussion}

\section{Weed species composition}

The weed community was composed of 12 species. Tab. 1 shows the weed species and weed dry weight. The dominant weed species were $C$. album, $A$. blitoides, $A$. retroflexus and $C$. arvensis (Tab. 1). All the species are representative of common potato fields in west region of Iran. C. album had the highest weed biomass $\left(132.4 \mathrm{~g} \mathrm{~m}^{-2}\right)$ and Portulaca oleracea had the lowest weed biomass $\left(3.1 \mathrm{~g} \mathrm{~m}^{-2}\right)$ in the total weed infestation treatment. The weeds biomass increased with increasing duration of the weed infestation and decreased with increasing duration of the weed free period (Fig. 1). These results agree with Thackral et al. (1989) who stated that the total dry weight of weeds the greatest in the unweeded control, followed by weeding at 10 weeks after planting treatment. The results showed that C. album because of the highest dry weight had the most effect on the loss potato yield (Tab. 1). Since C. album is one of the most dangerous weeds which emerge in the beginning of growing season in the potato fields, therefore this subject has an important role in time of weed removal and choosing a suitable method for weed control in the 
Tab. 1. Weed composition and average dry weight $\left(\mathrm{g} \mathrm{m}^{-2}\right)$ in weed-free control measured at the crop harvest

\begin{tabular}{cc}
\hline Weed species & Dry weight \\
\hline Chenopodium album & 132.43 \\
\hline Amaranthus blitoides & 126.07 \\
Amaranthus retroflexus & 71.93 \\
\hline Convolvolus arvensis & 31.30 \\
\hline Echinocloa crusgali & 15.33 \\
\hline Orobanch egyptica & 11.30 \\
\hline Daucus carotta & 10.60 \\
\hline Heliotropiam sp. & 10.17 \\
Tribolus trestris & 7.17 \\
\hline Eragrostispoaoides & 6.73 \\
\hline Cynodon dactylon & 4.67 \\
Portulaca oleraceae & 3.10 \\
Weed total weight & 430.8 \\
\hline
\end{tabular}

potato fields. A. blitoides and A. retroflexus were emerged after than $C$. album, therefore were competed at short time with potato. Since these weeds emerged later than $C$. album, thus it can be concluded which of them had lower damage for potato.

\section{Leaf area index (LAI)}

Leaf area index (LAI) had a similar trend in all treatments regardless of the durations of weed free and the weed infestation periods (Fig. 2). As in the beginning of growing season, potato LAI increased gently and about

Tab. 2. Parameter values for response curves based on Schumacher's model (a) and exponential model (b)

\begin{tabular}{cccc}
\hline Equation model & $\mathrm{A}$ & $\mathrm{B}$ & $\mathrm{R}^{2}$ \\
\hline (a) $\mathrm{Y}=\mathrm{e}^{\mathrm{a}+\mathrm{b} / \mathrm{x}}$ & 757.6417 & -0.00132 & 0.95 \\
(b) $\mathrm{Y}=\mathrm{ae} \mathrm{e}^{\mathrm{bx}}$ & 6.848766 & -1622.3 & 0.95 \\
\hline
\end{tabular}

55 days after emergence (DAE) attained to its maximum. Maximum LAI in the weed infestation was higher than the weed free and later reached its maximum in 5 days due to weed competition that indicates the higher weed damage in weed infest compared to weed free treatments.

Weeds decreased potato LAI, as at $55 \mathrm{DAE}$ (maximum LAI), in the weed interference periods until 10, 20, 30, 40 and $50 \mathrm{DAE}$ and in the seasonal-long weed infest than the seasonal-long weed free treatment, LAI decreased by 3.8 , 9.6, 19.2, 28.8, 32.7 and 36.5 percent, respectively (Fig. 2). The same was observed in the early growing season weed competition decreased LAI showing the important once of weed control in the beginning of growing season to attain higher yield. Results presented by Cox et al. (2006) regarding corn are supported by these results, too. They stated that weed interference in the early growing season caused reduction in LAI. Potato LAI also increased with prolonged weed free period, as the LAI is mostly attributed to the weed free treatment. Maximum LAI in the weed free periods until 10, 20,30, 40 and $50 \mathrm{DAE}$ and in the seasonal-long weed free treatment than those of seasonallong weed infest treatment increased by 7.5, 23, 35, 50, 53 and 61 percent, respectively (Fig. 2).
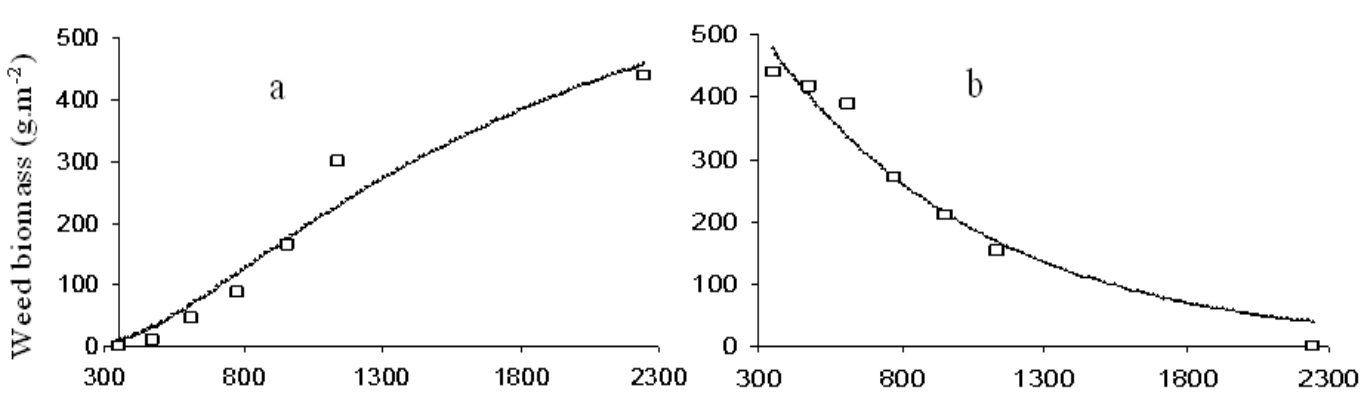

Duration of weed interference and weed free from crop sowing $\left(\mathrm{d}^{\circ} \mathrm{C}\right)$

Fig. 1. The effects of increasing duration of the weed interference (a) and the weed free (b) periods from crop sowing date on weed biomass. Symbols indicate observed data (see Tab. 2. for coefficients)

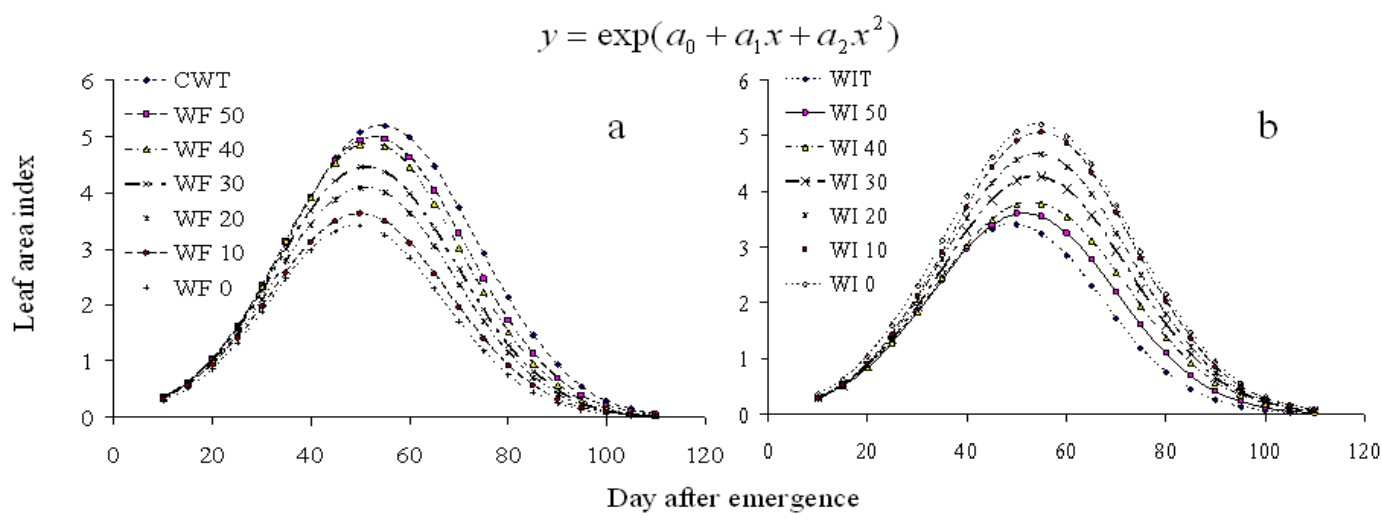

Fig. 2. The effects of increasing duration of the weed free (a) and the weed interference (b) periods from crop sowing date on leaf area index. Symbols indicate observed data 
46

Therefore the results showed that the weed free periods as compared to the weed infested periods had more effects on potato LAI. This subject indicates more important previously weeds control in various crops. Crotser and Witt (2000) showed that the weed free periods caused increase in LAI in the various crops, too. Weed removal caused reduction in weed competitiveness on potato. In the absence of weeds, light and more consuming factors absorbed by plant and this subject caused an increase in leaf area index and potato photosynthesis. Increased LAI caused an increase in light absorption and photosynthesis which led to an increase in total dry matter and potato yield. Cox et al. (2005) also reported weed competition reduced corn LAI.

\section{Leaf area index duration (LAID)}

The weed free and weed interference periods had a significant effect on Leaf area index duration (LAID) (Fig. 3). The most LAID was attributed to the seasonallong weed free treatment (244.4 LAI-day) and the lowest LAID are attributed to the weed infestation total treatment (148.6 LAI-day). With increasing duration of the weed interference period and decreasing duration of the weed free period LAID was reduced. Increasing the duration of the weed interference period caused a reduction of 39.2 percent LAID in the weed infestation treatment than that of the weed free treatment.

It seems that cause be of the weed shading on the potato's lower leaves these leaves were reached Light Compensation Point. This was a result of earlier abscission of leaves and as reduced LAI (Fig. 2) and LAID (Fig. 3). Fig. 3 showed that duration of the weed interference until 10 DAE and also duration of the weed interference after 30 DAE had similar effects on LAID. Therefore, weed competition between $30^{\text {th }}$ DAE and after $50^{\text {th }}$ DAE had the most effect on the reduction the LAID. Effects of duration of the weed free until $20 \mathrm{DAE}$ and duration of the weed free after 50 DAE was the same similar on LAID, too. Thus, the most important effect of weed control on
LAID saw between $20^{\text {th }}$ DAE until $50^{\text {th }}$ DAE. Therefore, we can conclude that the weed control between $20^{\text {th }} \mathrm{DAE}$ until $50^{\text {th }}$ DAE was more effective in increasing LAID. Hall et al. (1992) showed that weed competition in corn could be caused by decreasing LAID. Fig. 3 also shows that with increasing duration of the weed free period LAID increased, as increase of the weed free period caused an increase 64.5 percent LAID in the seasonal-long weed free treatment than that of the weed infestation treatment. Hall et al. (1992) stated that the corn LAID increased due to the reduction of weed competition. LAID is one of the traits in determining crop yield, weeds via decreasing potato LAI (Fig. 2), specially after tuber formation, caused more reduction in this index, thus potato yield showed a lot of loss itself.

\section{Potato light absorption}

Regardless of the duration of the weed interference period, potato light absorption increased with increasing LAI. The light absorption reached the maximum amount of about 55 DAE. It was 83 percent for the weed free treatment (Fig. 4) after that (about 60 DAE) light absorption due to reduction LAI and lodging of potato canopy, had decreasing trend and until the final stage of growing season reduced gently. Weed competition resulted in the reduction of potato light absorption, as at duration of the weed interference until 10,20,30, 40 and $50 \mathrm{DAE}$ and in the weed infestation total treatment than the weed free total treatment, potato light absorption decreased by 2.4 , 8.1, 17.4, 22.1, 27.3 and 31.4 percent, respectively (Fig. 4). Potato light absorption increased with increasing duration of weed free period, too (Fig. 4). Maximum light absorption at duration of the weed free until 10, 20,30, 40 and $50 \mathrm{DAE}$ and the weed free total treatment than the weed infestation total treatment, increased by 7.6, 16.7, 29.3, 45.8, 54.9 and 58.9 percent, respectively (Fig. 4). Some researchers stated that with the increasing of population and biomass of oat (Avena fatua) in wheat (Cudney et al., 1989) and barley (Lish and Thin, 1990) light absorp-

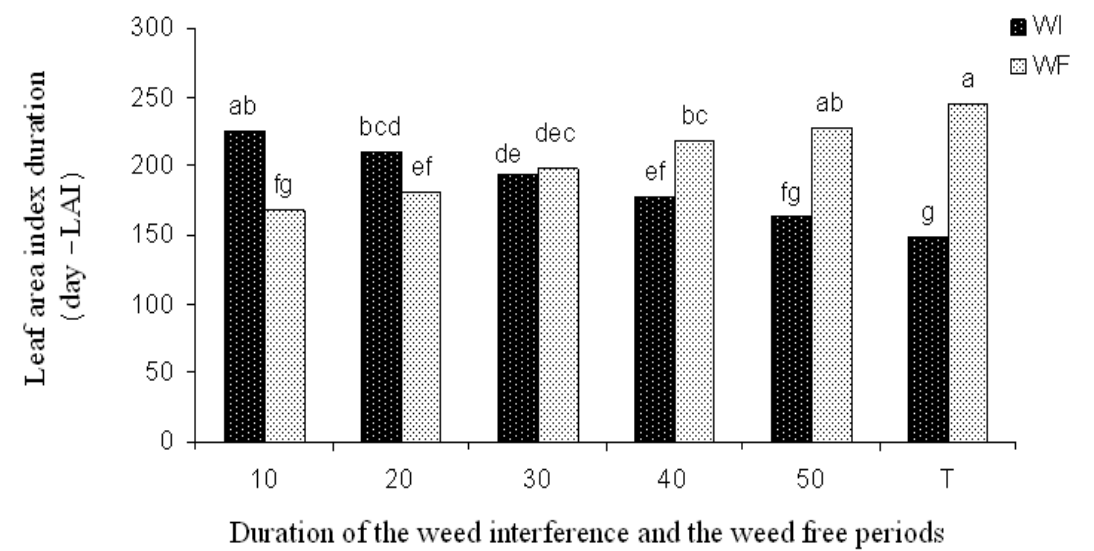

Fig. 3. The effects of increasing duration of the weed free (WF) and the weed interference (WI) periods from crop sowing date on leaf area index duration 
tion by crop canopies was decreased resulting in reduced crops yield. Moreover, results showed in comparison to the durations of the weed free than durations of the weed interference had higher effects on potato light absorption. This subject shows the more importance of weed control at the beginning of the growing season to inhibit decrease of light absorption. This subject is the reason of decrease in photosynthesis and dry matter accumulation. Other investigations showed that the increase in light absorption by crops caused to increase their compatibility against weeds that this subject caused to increase in the crops yield (Mesbah et al., 1995).

One of the most important targets in field management, especially in relation with weed competition against crops, is the most capture of sun energy by crops. This subject was reason for the increase crops yield. Among effective factors in competition, light is one of the most important environmental factors, because there isn't any location for saving light (Daugovish et al., 1999).

\section{Light extinction coefficient $(K)$}

Light extinction coefficient $(K)$ is one of the canopy characteristics structure. The results showed that there was a significant effect on the $\mathrm{K}$ in the potato canopy. Maximum $\mathrm{K}$ was related to the weed free total treatment $(0.432)$ and minimum $\mathrm{K}$ was related to the weed infestation total treatment (0.298) (Tab. 3). By increasing the du-
Tab. 3. The effects of increasing duration of the weed free and the weed interference periods from crop sowing date on light extinction coefficient

\begin{tabular}{|c|c|c|c|c|c|c|}
\hline \multicolumn{7}{|c|}{$\begin{array}{l}\text { Duration of the weed free and the weed } \\
\text { interference periods (day) }\end{array}$} \\
\hline & 0 & 10 & 20 & 30 & 40 & 50 \\
\hline interference & $0.432 \mathrm{a}$ & $0.422 \mathrm{a}$ & $0.392 \mathrm{ab}$ & $0.333 \mathrm{ab}$ & $0.303 \mathrm{~b}$ & $0.299 \mathrm{~b}$ \\
\hline free & $0.289 \mathrm{~b}$ & $0.289 \mathrm{~b}$ & $0.311 \mathrm{~b}$ & $0.337 \mathrm{ab}$ & $0.387 \mathrm{ab}$ & $0.430 a$ \\
\hline
\end{tabular}

ration of the weed interference the $\mathrm{K}$ decreased gently, as the total weed interference period in comparison to total weed free period, resulted to decrease 30.5 percent in the K. Tab. 3 also shows that the significant effects of long of the weed free periods on the K. Increasing the weed free period than the weed infestation increased 45 percent in the $\mathrm{K}$ which shows the more important weed control for the $\mathrm{K}$ in the early of the growing season in comparison to the end of growing season, too. It seems that weeds via decreasing potato LAI (Fig. 2) and number of stem minor (results not shown) resulted to decrease in $\mathrm{K}$.

\section{Radiation use efficiency (RUE)}

Radiation use efficiency (RUE) reduced with the decrease in duration of the weed free period and increasing duration of the weed interference period. The lowest

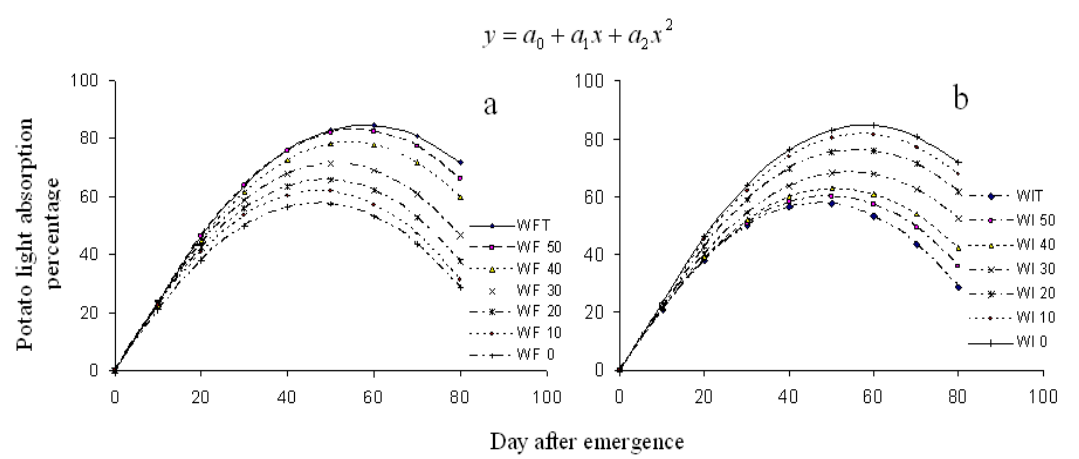

Fig. 4. The effects of increasing duration of the weed free (a) and the weed interference (b) periods from crop sowing date on light absorption. Symbols indicate observed data

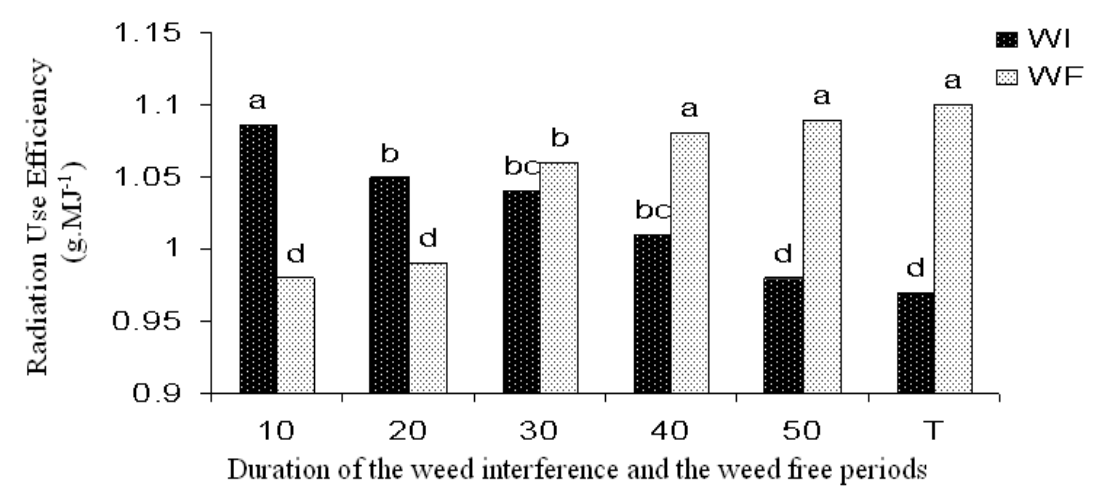

Fig. 5. The effects of increasing duration of the weed free (WF) and the weed interference (WI) periods from crop sowing date on Radiation Use Efficiency 
48

RUE could be attributed to the weed infestation treatment $\left(0.97 \mathrm{~g} \mathrm{MJ}^{-1}\right)$ and the highest RUE was attributed to the weed free treatment $\left(1.10 \mathrm{~g} \mathrm{MJ}^{-1}\right)$ (Fig. 5). RUE in the weed infestation treatment in comparison to the weed free treatment, reduced 11.8 percent (Fig. 5). It seems that weeds via competition for resources and decreasing photosynthesis and dry matter accumulation (Fig. 7) resulted in the decrease in potato RUE. Cavero et al. (1999) also showed that with decreasing prolong of the weed free RUE of corn reduced.

There wasn't any significance difference between RUE for the weed free period until $20 \mathrm{DAE}$ and the weed free after 40 DAE (Fig. 5). Therefore, weed control from $20^{\text {th }}$ DAE until $40^{\text {th }}$ DAE had the most positive effect in RUE. Because critical period of weed control in potato also attained the confine (Fig. 9), thus, it can introduced that reduction of the RUE in this period as one of the effective factors in reducing potato yield. Beyshlang et al. (1990) also stated that, wheat RUE had a significant loss in competition with wild oat (Avena fatua).

Monteith (1977) reported a linear relation between dry matter accumulations and light absorption. The slope of this linear regression is the RUE which it is adequate with net photosynthesis (Monteith, 1977). To determine the effects of weed competition on RUE and photosynthetically active radiation is very important (PAR). Weeds competition for light caused to prevent consume of light optimum in the crops canopy. Since light is one of not savable sources by plant thus all negative effects produced in light consuming by crops, resulted to decrease crops competitiveness against weeds which reduce qualitative and quantitative crops yield finally.

\section{Crop growth rate (CGR)}

The results showed that CGR reached to a maximum of about 55 DAE in all treatments. In weed free treatment, CGR was $26 \mathrm{~g} \mathrm{~m}^{-2}$ day ${ }^{-1}$ (Fig. 6). Because of aging and abscission of bottom the leaves and the decreasing in ability of their photosynthesis ability, CGR detected a reducing trend of about 60 DAE.

Durations of the weed interference and the weed free had a significant effect on CGR (Fig. 6). With prolonged of the weed interference CGR reduced gently. Weed competition in the interference treatments until 10, 20, 30, 40 and $50 \mathrm{DAE}$ and in the weed infestation total treatment in comparison to the weed free total treatment caused a decrease in CGR about 5.6, 13.9, 24.2, 28.2, 34.1 and 40.1 percent, respectively (Fig. 6). This subject maybe is due to sooner abscission of leaves at down of canopy and more falling rate of because of weed interference, light competition and weed shading on potato. Therefore, through Yield Constancy Law, content of dry matter in a unit of the land area is a content of auxiliary. Thus, through to this law, with increasing the duration of the weed interference

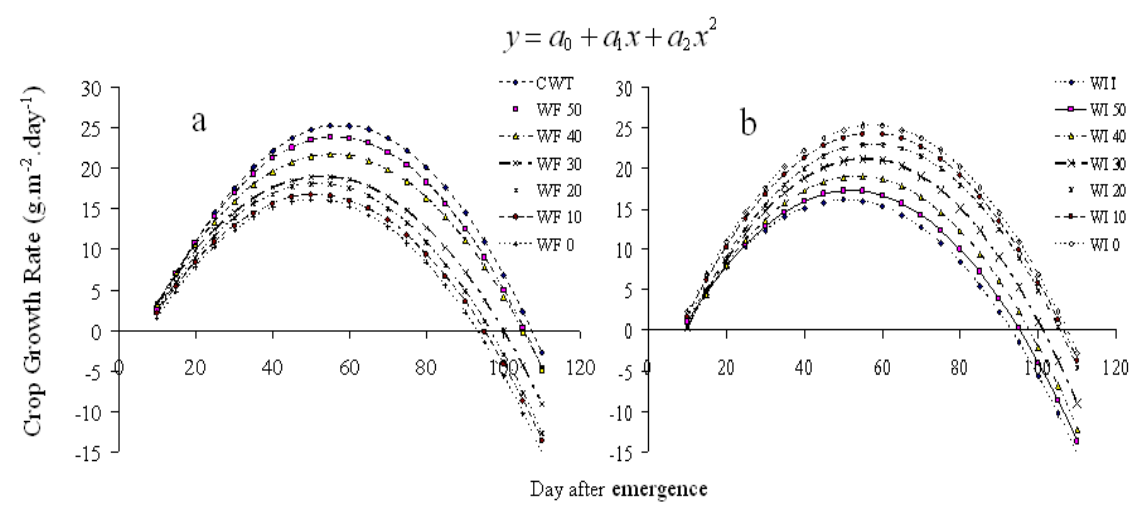

Fig. 6. The effects of increasing duration of the weed free (a) and the weed interference (b) periods from crop sowing date on crop growth rate. Symbols indicate observed data

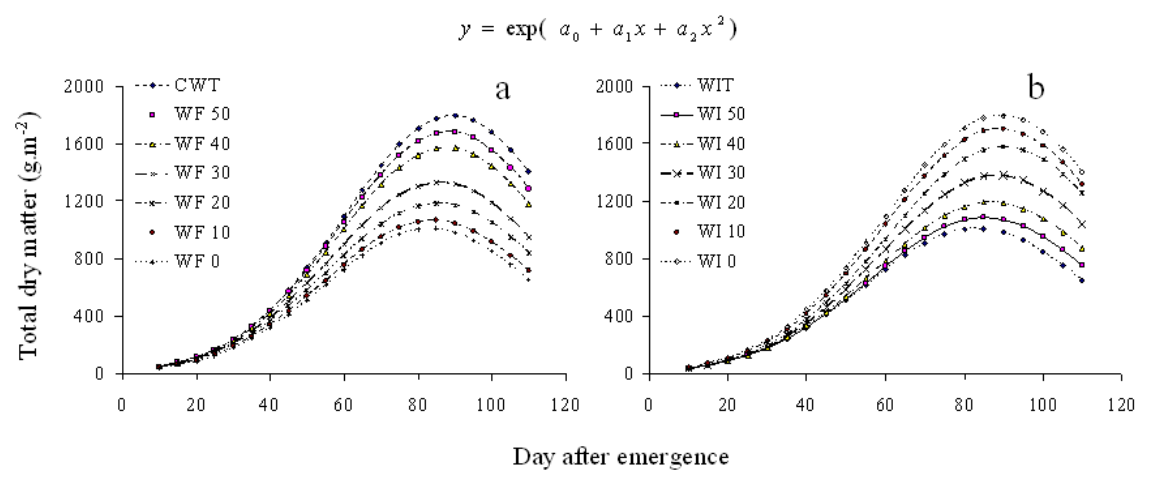

Fig. 7. The effects of increasing duration of the weed free (a) and the weed interference (b) periods from crop sowing date on total dry matter. Symbols indicate observed data 
period, increased total weed dry weight (Tab. 1), thus total dry matter of potato in a unit of the land area reduced (Fig. 7), therefore, because of strong relationship between dry weight of potato and potato growth rate this result was acceptable. Cathcart and Swanton (2004) indicated that with increasing duration of the weed infested, corn CGR decreased extremely, too. Moreover, results showed that CGR increased with the increase in the duration of weed free period (Fig. 6), as weeds were removed in the weed free periods until 10, 20,30, 40 and $50 \mathrm{DAE}$ and the weed free total period than the weed infestation period, maximum of potato CGR increased by $4,13,19,36$, 49 and 58 percent, respectively. Decrease in corn CGR in competition against Datura sp. (Cavero et al., 1999) and Cynodon dactylon (Fernandez et al., 2002) was reported, too. Moreover, Ahmadvand et al. (2009) stated that one of the important factors in successful crops against weed competition is higher crop CGR. Hargood et al. (1981) reported that CGR is a proper index for studying crops competitiveness against weeds, too. CGR is the growth indices which are calculated for showing effects of limiting environmental factors in the most crops. CGR has a direct relation with LAI and total dry matter, as each type reduction in these indices that cause a decrease in CGR.

\section{Total dry matter (TDM)}

In the beginning of the growing season the trend of total dry matter accumulation of potato in the weed free and the weed infestation periods was in the same. Because in the beginning of growing season the plants were very small thus there was not interference and competition between crop and weeds. Weed competition started at about $40 \mathrm{DAE}$ and intensified with the increase in the duration of the weed interference period and decreasing duration of the weed free period (Fig. 7). With increasing duration of the weed interference period, potato TDM reduced, as in about $90 \mathrm{DAE}$, in the weed infestation treatments until 10, 20. 30, 40 and $50 \mathrm{DAE}$ and in the weed infestation total treatment than those of the weed free total treatment TDM decreased 4.4, 10.2, 12.2, 23.3, 37.8 and 44.4 per- cent, respectively (Fig. 7). Cox et al. (2005) also showed that weed competition against corn in the beginning of growing season reduced TDM. Moreover, increasing the duration of the weed free period was a reason for the increase in potato TDM. As in the weed free treatments until 10, 20, 30, 40 and 50 DAE and in the weed free total treatment in comparison to the weed infestation total treatment TDM increased 9, 22, 34, 56, 67 and 79 percent, respectively (Fig. 7). These results correspond to the results obtained by Bukun (2004), who stated that cotton TDM increased with increasing the duration of the weed free period gently. Amador-Ramirez (2002) also inducted in experimental on pepper that increasing duration of the weed free period caused to increase pepper yield.

Weed proximity with potato during growing season or abundant part of the growing season reason a reduction potato dry matter. Weeds usually decrease TDM in the various crops via both competition for resource and allelopathy. These results were in accordance with the results attained by Traore et al. (2003), they indicated that sorghum (Sorghum vulgare) TDM in competition with Abotylon tephrasti reduced extremely because of consumed resources. Leaf area index is the most important factor which resulted in the increase of total dry matter in various crops. LAI with TDM have a direct relation. Weed via competition for limiting factors for example, light, water and nutrient was reason for reduction LAI (Fig. 2), LAID (Fig. 3) and light absorption (Fig. 4) by potato canopy. Thus potato photosynthesis and dry matter accumulation reduced. This subject caused a reduction in potato TDM against weed competition.

\section{Final tuber yield}

The obtained results showed that duration of the weed interference period had a significant effect on the final tuber yield. The potato final tuber yield reduced with increasing the duration of the weed interference period, as in the weed infestation total treatment in comparison with the weed free total treatment, with reduction 54.8 percent, the tuber yield of potato reduced from $66170 \mathrm{~kg} \mathrm{ha}^{-1}$

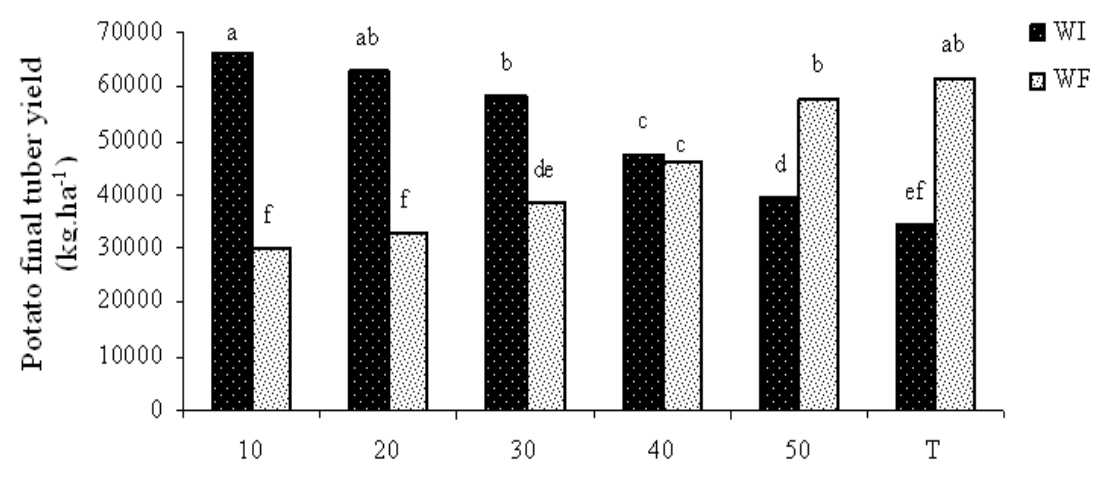

Duration of the weed interference and the weed free periods

Fig. 8. The effects of increasing duration of the weed free (WF) and the weed interference (WI) periods from crop sowing date on final tuber yield 
50

Tab. 4. Parameter values for tuber yield response curves based on logistic model: $\mathrm{Y}=\left(\mathrm{C}+\mathrm{D} /\left(1+\exp \left(-\mathrm{A}+\mathrm{B}^{*} \mathrm{GDD}\right)\right)\right)$

\begin{tabular}{ccccc}
\hline \multicolumn{5}{c}{ Coefficients } \\
\hline $\mathrm{A}$ & $\mathrm{B}$ & $\mathrm{C}$ & $\mathrm{D}$ & $\mathrm{R}^{2}$ \\
\hline 4.432431 & 0.005897 & 45.65407 & 59.65908 & 0.99 \\
\hline
\end{tabular}

Tab. 5. Parameter values for tuber yield response curves based on Gompertz model: $\mathrm{Y}=\mathrm{A}^{*} \exp \left(-\mathrm{B}^{*} \exp \left(-\mathrm{K}^{*} \mathrm{GDD}\right)\right)$

\begin{tabular}{cccc}
\hline \multicolumn{4}{c}{ Coefficient } \\
\hline $\mathrm{A}$ & $\mathrm{B}$ & $\mathrm{K}$ & $\mathrm{R}^{2}$ \\
\hline 103.5984 & 2.101224 & 0.002323 & 0.96 \\
\hline
\end{tabular}

to $29940 \mathrm{~kg} \mathrm{ha}^{-1}$ (Fig. 8). This is in agreement with Thackral et al. (1989) who stated that with increasing duration of the weed infestation potato tuber yield decreases significantly. Bukun (2004) reported similar results on biomass and plant height of cotton, too. Amador-Ramirez (2002) and Mohammadi et al. (2004) also reported similar results on pepper and chickpea, respectively. The reduction trend of potato tuber yield could be related to weed shading and reduction potato yield components (results not shown). Petroviene (2002) showed that the final tuber yield of potato reduced with increase in the duration of the weed interference period, too. Fig. 8 also showed that, potato final tuber yield had a significant increase with increasing duration of the weed free period. 50 days of the weed free period is sufficient to increase the potato final tuber yield 121 percent in comparison to the weed infestation treatment (Fig. 8). Petroviene (2002) showed that potato final tuber yield increased with the increase in the duration of the weed free period, too.

It seems that in the weedy conditions intensified intercompetition and pressure of the weed biomass resulted in the reduction in potato yield. Potato final yield did not show a significant difference between duration of the weed free until $20 \mathrm{DAE}$ and durations of the weed free after 50 DAE (Fig. 8). In fact after 50 DAE weeds were
Tab. 6. Onset and end of the critical period of weed control in potato based on growth degree days (GDD) and days after emergence (DAE)

\begin{tabular}{cccccccc}
\hline \multicolumn{3}{c}{$10 \% \mathrm{AYL}^{*}$} & \multicolumn{4}{c}{$5 \%$ AYL } \\
\hline \multicolumn{2}{c}{ onset } & \multicolumn{2}{c}{ end } & \multicolumn{2}{c}{ onset } & \multicolumn{2}{c}{ end } \\
\hline DAE & GDD & DAE & GDD & DAE & GDD & DAE & GDD \\
51 & 1164 & 19 & 572 & 63 & 1372 & 11 & 486 \\
\hline
\end{tabular}

${ }^{*}$ Acceptable yield loss level

not able to compete with potato and weed controls were due to decrease in weed dry weight. Weed competition did not have any effect on potato final yield in beginning of the growing season. The reason for this subject was small size and demand of plants, abundance of resource and finally didn't start competition between weeds and potato. Therefore with reference to these results, a control period between $20^{\text {th }}$ DAE until $60^{\text {th }}$ DAE was sufficient for inhibition from potato yield reduction. This period accorded to critical period of the weed control in potato. Thackral et al. (1989) reported increasing in potato final yield because of increasing duration of the weed free period, too.

\section{The critical period of the weed control (CPWC) in potato}

Predicted and observed relative potato yield being affected by duration of the weed-infested or weed-free periods are shown in Fig. 9. The onset of the CPWC in potato was calculated from the above mentioned equations became earlier as the predetermined acceptable yield loss level (AYL) increased from 5\% to $10 \%$ (Tab. 6). The beginning of the CPWC was 486 GDD at 5\% AYL and 572 GDD at 10\% AYL (Tab. 6). This equates to 11 and 19 DAE, respectively. The end of the CPWC was 1372 GDD at $5 \% \mathrm{AYL}$ and $1064 \mathrm{GDD}$ at $10 \% \mathrm{AYL}$, which equates to 63 and $51 \mathrm{DAE}$, respectively. The end of the CPWC increased as the AYL decreased from $10 \%$ to $5 \%$ (Tab. 6). Results showed that since the potato tubers were planted in $75 \mathrm{~cm}$ rows, therefore in the beginning of the growing a

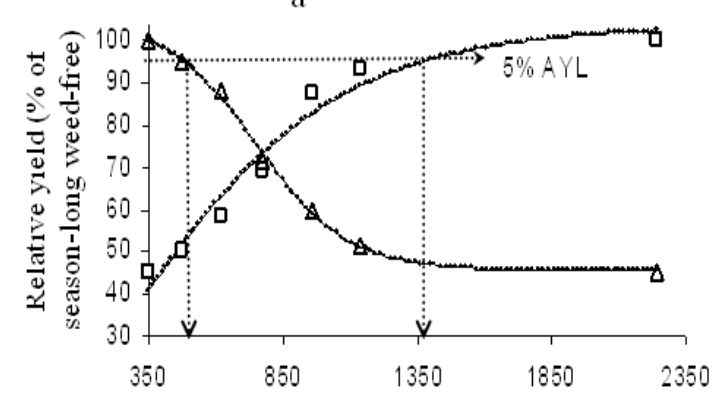

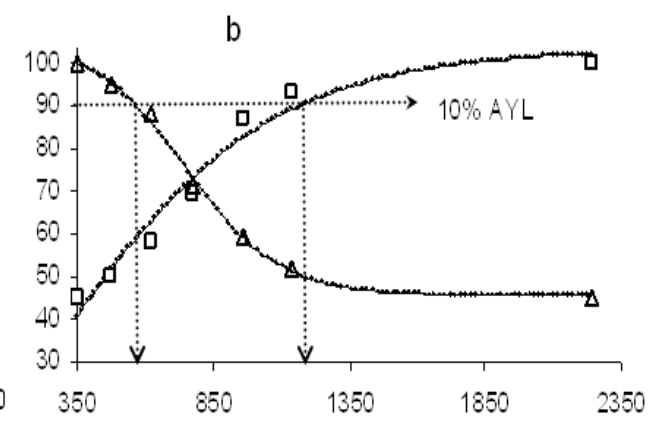

Growing degree days after sowing $\left(\mathrm{d}^{\circ} \mathrm{C}\right)$

Fig. 9. Effect of the weed interference on potato relative yield. Increasing duration of the weed interference (triangles) and fitted curves as calculated by the logistic equation. Increasing duration of the weed free period (squares) and fitted curves as calculated by the Gompertz equation. Symbols represent observed data. Horizontal dashed lines indicate the 5\% (a) and 10\% (b) acceptable yield loss level respectively used to determine the CPWC, whereas vertical dashed lines indicate the beginning and the end of CPWC. Parameters for fitted curves given in Tab. 4 and 5 
season due to abundance in consuming resources and no weed proximity with crop, weeds had no economic damage. Thus in range 15 until $20 \mathrm{DAE}$ did not need weed control. Moreover, results indicated that from 55 until 60 DAE weeds presence had no the economic damage. Thus, it is recommended that after outwear this period farmers do not apply the weed control methods (whereas their field conditions is equal to our field condition). Because after finishing this period, crops dominate on weeds due to their canopy extension and high competitiveness. Thus they will be able to prevent from weeds damage. This is in agreement with the findings of Thackral et al. (1989) who showed that maximum yield of potato was obtained where plots were kept weed-free, followed by weeding at 4 to 6 weeks after planting. Baziramakenga and Leroux (1994) in another experiment reported that the onset of the CPWC was $15 \mathrm{DAE}$ and the end of the CPWC was between 23 to $68 \mathrm{DAE}$ in potato. The environmental and field conditions affected the CPWC extremely (Baziramakenga and Leroux, 1994; Ford and Pleasant, 1994). This subject can be the reason of problems in this experiment results with other experiment results. Snipes et al. (1987) showed that the critical period for $X$. strumarium control in cotton started 2-4 weeks after emergence and ended 8-10 weeks after emergence. Papamichail et al. (2002) reported that the critical period of competition from a mixed weed flora in cotton started 3-5 WAE and continued until 11 WAE in order to avoid a reduction in cotton growth and yield, too.

The length of the CPWC in potato was 52 and 32 days at $5 \%$ and $10 \%$ AYL, respectively (Tab. 6). Control of potato weeds according to $5 \%$ AYL is not recommendable because of both increased weed control costs and due to closed potato canopy, weed control in this period resulted in more damage.

Potato needs 1 or 2 times of hilling at 3 to 4 weeks of its beginning of the growing season. Since this stage equals with the CPWC, therefore it can be used the hilling practice according to tillage by cultivation for decreasing consumption of herbicides. Development of an Integrated Weed Management System (IWM) requires knowledge on the behavior of weeds in the agro-ecosystem, including possible effects on crop yield (Amador-Ramirez, 2002). The CPWC is a key component of strategies for IWM and the results of this experiment contribute to the development of such a system for Iranian potato growers. The definitions of the critical period of weed control support the early suppression of weeds using pre-emergence herbicides or cultivation, amount would depend on weed pressure (Swanton and Weise, 1991). Since herbicides are used in various crops and this is increasing all around the world and have side effects herbicides damage on human health and environment and reducing biodiversity and genetic erosion it seems such investigations can be one step for moving toward sustainable agricultural.

\section{References}

Ahmadvand G, Mondani F, Golzardi F (2009). Effect of crop plant density on critical period of weed competition in potato. Sci Hort 121:249-254.

Amador-Ramirez MD (2002). Critical period of weed control in transplanted chilli pepper. Weed Res 42:203-209.

Arnold RN, Murray MN, Gregory EJ, Smeal D (1998). Weed control in field potatoes. Agricultural Experiment Station. Research Report 723 College of Agriculture and Home Economics.

Bange MP, Hawwer GL, Rickert KG (1997). Effect of leaf nitrogen on radiation use efficiency and growth of sunflower. Crop Sci 37:1201-1207.

Baziramakenga R, Leroux GD (1994). Critical period of quick grass (Elytrigia repens) removal in potatoes (Solanum tuberosum). Weed Sci 42:528-533.

Beyshlang W, Barnes PW, Ryel R, Caldwell MM, Flint SD (1990). Plant competition for light analyzed with a multispecies canopy model. Oecologia 82:374-380.

Board JE, Harville BG, Soxton AM (1990). Branch dry weight in relation to yield increases in narrow-row soybean. Agron J 82:540-544.

Bukun B (2004). Critical period for weed control in cotton in Turkey. Weed Res 44:404-412.

Cathcart RJ, Swanton CJ (2004). Nitrogen and green foxtail (Setaria viridis) competition effects on corn growth and development. Weed Sci 52:1039-1049.

Cavero J, Zaragoza M, Suso DT, Pardo PN (1999). Competition between maize and Datura stramonium in an irrigated field under semi- arid conditions. Weed Res 39:225-231.

Cooper RL (1977). Response of soybean cultivars to narrow rows and planting rates under weed- free conditions. Agron $\mathrm{J}$ 69:89-92.

Cox JW, Hahn RR, Stachowski PJ, Cherney JH (2005). Weed interference and glyphosate timing affect corn forage yield and quality. Agron J 97:847-853.

Cox JW, Hahn RR, Stachowski PJ (2006). Time of weed removal with glyphosate affects corn growth and yield components. Agron J 98:349-353.

Crotser PM, Witt WW (2000). Effect of Glycine max canopy characteristics, G.max interference, and weed-free periods in Solanum ptycanthum growth. Weed Sci 48:20-26.

Cudney DW, Jordan LS, Holt JS, Peints JS (1989). Competition interaction of wheat (Triticum aestivum) and wild oats (Avena fatua) grown at different densities. Weed Sci 37:538543.

Daugovish O, Lyon DJ, Baletensperger DD (1999). Cropping systems to control winter annual grasses in winter wheat (Triticum aestivum). Weed Technol 13:120-126.

Elkoca E, Kantar F, Zengin H (2005). Weed control in lentil (Lens culinaris) in eastern Turkey. NZ J Crop Hort Sci 33:223-231. 
52

Fernandez ON, Vignolio OR, Requesens EC (2002). Competition between corn (Zea mays) and Bermuda grass (Cynodon dactylon) in relation to the crop plant arrangement. Agron J 22:293-305.

Ford GT, Pleasant JM (1994). Competitive abilities of six corn (Zea mays L.) hybrids with four weed control practices. Weed Technol 8:124-128.

Gardner FP, Pearce RB, Mitchell RL (1985). Physiology of Crop Plants. Iowa State University Press, USA, p. 186-208.

Hall MR, Swanton CJ, Anderson GW (1992). The critical period of weed control in grain corn (Zea mays). Weed Sci 40:441-447.

Hargood ES, Bauman JT, Williams JL, Schreiber MM (1981). Growth analysis of soybean (Glycine max L.) in competition with jimson weed (Datura stramonium L.). Weed Sci 6:572574.

John RT, Frank JR (1983). Effects of row spacing on weed competition with snap bean (Phaseolus valgaris). Weed Sci 31:81-85.

Knezevic ZS, Evans SP, Blankenship EE, Van Acker RC, Lindquist JL (2002). Critical period for weed control: the concept and data analysis. Weed Sci 50:773-786.

Lish J, Thin D (1990). Fertilizer placement-row spacing effects on wild oat. Conservation tillage Hand Look Series. Chapter 5. Weed Control.

Mesbah A, Miller SD, Fornstrom KJ, Legg DE (1995). Wild mustand (Brassica kaber) and wild oat (Avena fatua) interference in sugar beets (Beta vulgaris). Weed Technol 9:49-52.

Mohammadi G, Javanshir A, Khooie FR, Mohammadi SA, Zehtab S (2004). Critical period of weed interference in chickpea. Weed Res 45:57-63.

Monteith JL (1977). Solar radiation and productivity in tropical ecosystems. J Appl Ecol 9:747-766.

Morin L, Reid AM, Sims-Chilton NM, Buckley YM, Dhileepan K, Hastwell GT, Nordblom TL, Raghu S (2009). Review of approaches to evaluate the effectiveness of weed biological control agents. Biol Control 51:1-15.

Muurinen S, Peltonen-Sainio P (2006). Radiation-use efficiency of modern and old spring cereal cultivars and its response to nitrogen in northern growing conditions. Field Crops Res 96:363-373.

Nassiri Mahallati M (1998). Modeling interactions in grassclover mixtures. PhD Thesis. Wageningen Agricultural University.
Papamichail D, Eleftherohorinus I, Froud-Williams R, Gravanis $\mathrm{F}$ (2002). Critical periods of weed competition in cotton in Greece. Phytoparasitica 30:1-7.

Petroviene I (2002). Competition between potato and weeds on Lithuania's sandy loam soils. Weed Res 12:286-287.

Ratkowsky DA (1990). Handbook of Nonlinear Regression Models. Marcel Dekker, New York, USA.

Rouphael Y, Colla G (2005). Radiation and water use efficiencies of greenhouse zucchini squash in relation to different climate parameters. Europ J Agron 23:183-194.

Roush ML, Radosevich SR (1985). Relationship between growth and competitiveness of four annual weed. J Appl Ecol 22:895-905.

SAS Institute (1999). The SAS system for Windows. Version 9.1 SAS Inst., Cary, NC.

Schumacher FX (1939). A new growth curve and its application to timber-yield studies. J For 37:819-820.

Shurong H, Ashley A, Boerma HR (1993). Light intensity, row spacing, and photoperiod effects on expression of braychytic stem in soybean. Crop Sci 33:29-37.

Sit V, Costello MP (1994). Catalog of Curves for Curve Fitting. Biometrics Information Hand book Series. Ministry of Forests BC. Victoria Canada. ISSN 1183-9759: No.4.

Snipes CE, Street JE, Walker RH (1987). Interference periods of common cocklebur (Xanthium strumarium) with cotton (Gossypium hirsutum). Weed Scie 35:529-532.

Spitters CTT, Kramer TH (1986). Differences between spring wheat cultivars in early growth. Euphytica 35:273-292.

Stagnari F, Pisante M (2011). The critical period for weed competition in French bean (Phaseolus vulgaris L.) in Mediterranean areas. Crop Protect 30:179-184.

Stephen ST, Mason C, Maryin AR, Mortensen DA, Spotanski JJ (2003). Velvetleaf interference effects on yield and growth of grain sorghum. Agron J 95:1602-1607.

Swanton CJ, Weise SF (1991). Integrated weed management: the rationale and approach. Weed Technology 5:657-663.

Thackral KK, Pandita ML, Khurana SC, Kaloo G (1989). Effect of time of weed removal on growth and yield of potato. Weed Res 29:33-38.

Traore S, Mason SC, Martin AR, Mortensen DA, Spotanski JJ (2003). Velvetleaf interference effects on yield and growth of grain sorghum. Agron J 95:1602-1607. 